\title{
PECULIARITIES OF ORGANIZATION OF INDEPENDENT WORK OF STUDENTS IN GEOGRAPHY CLASSES
}

\author{
Kateryna Tymonchuk ${ }^{1}$ \\ ${ }^{I}$ graduated from the Department of Geography and Geoecology, Volodymyr Vynnychenko Central Ukrainian \\ State Pedagogical University, Kropyvnytskyi, Ukraine, e-mail: timoncukkaterina98@gmail.com, ORCID: \\ https://orcid.org/0000-0002-8217-9096
}

Abstract. The article reveals the essence of concepts «independent work» and «independent activity", their common and distinctive features, the peculiarities of the organization of students' independent work in geography lessons; using this teaching method to form students' geographical picture of the world; the role of students' independent work in the process of developing their desire to self-deepening geography knowledge, their ability to creatively search, the activation of independent creative cognitive activity, deepening cognitive interest, educational and cognitive motivation, development of students' educational competencies.

The author substantiates the expediency of using independent work at elementary school geography courses, reveals its educational and developing value. The types and methods of students' independent work, its role in the formation of students' critical thinking, creative abilities, skills and abilities working with the map and other sources of geographical information are characterized in the article. Approaches to the classification of students' independent work are studied, the interrelation of class and home independent work is considered. Various types of students' independent work in geography lessons are analyzed to evaluate their effectiveness. The structure of implementation and methods of task development of students' independent work and the system of their complication are revealed. Examples of tasks of different levels of complexity and degrees of independence are given. The article summarizes the results of the research conducted by the author about the evaluation of the effectiveness of various methods of students' independent work in geography lessons. The reasons of the efficiency of the investigated methods are revealed.

Keywords: students' independent work, types and methods, geography lesson, effectiveness of methods, organization of students' independent work in geography lessons, tasks for independent work.

JEL Classification: JEL I0; I20

Formulas: 0; fig.: 2, tabl.: 1; bibl.: 7

Introduction. Education of students' independence, critical thinking, ability to creative search is one of the leading tasks of the modernization of the educational content. Each student in class must be an active participant in the learning process according to their individual abilities. In this regard, there is a need to form students' general and special skills and abilities of independent acquisition of knowledge.

The main task of modern education is to prepare students for life in the modern conditions of the dynamic world. So it is necessary to teach children to think independently, critically and creatively, to solve problems, use information wisely, work with it, learn throughout the life, to show initiative not only in their work but also in society.

The main task of modern geography is not only to describe countries and their geographical features, but also scientifically substantiate the work of mankind on the rational use of natural resources, transformation and preservation of the natural environment. The relevance of the topic is to develop and justify an effective system for organizing students' independent learning activities in the structure of the lesson. 
The main task of modern school is teaching students to acquire knowledge independently. The further mental development of the young generation will depend this which will not only on applying the acquired knowledge independently but also master new skills and improve them.

Even though this topic has been repeatedly studied by many scientists in various scientific fields, the study of methods, types and features of the organization of students' independent work in geography lessons remains relevant.

Literature review. Independence, independent work, independent creative activity were the subject of scientific research by many scientists: philosophers, psychologists, didactics, methodologists (P.V. Kopnin, O.M. Korshunova, B.G. Bogoyavlenskaya, Y.A. Ponomarev, V.I. Andreev, B.I. Korotyaev, I.Y. Lerner, I.S. Zorenko, S. Miroshnyk, V.O. Korynska, A.P. Kovaleva, M. Medvedev, G. Lemekin, etc.). However, each of them has different approaches to defining the concept of «independent work» [3].

Aims. The main purpose of the research is to give students a geographical picture of the world through various types of independent work in the process of educational and cognitive activities.

Methods. While writing the article, we used such general scientific methods as: search and analysis of literature sources, systematization, comparison, analysis, synthesis, classification, logical generalization, pedagogical observation, conversations, surveys.

Results. The students' independent work is the method of teaching, which aims at the performance of tasks by students in order to acquire knowledge, the formation of abilities and skills of development of mental and motor (motor) activity. Independent work is widespread in lessons, laboratory-practical classes, workshops, excursions, annual work practice.

In general, the structure of students' independent work is such:

- receiving a task from the teacher and considering its content;

- awareness of the purpose of future activities, mobilization of knowledge, skills, practical experience;

- planning future activities;

- task performance; making adjustments, the implementation of self-control;

- analysis of work results (comparing them with the purpose).

Independent work is a versatile, multifunctional phenomen and has not only educational, but also personal, social significance. This is the highest form of student learning, which is a form of self-education [4].

The article studies, develops and substantiates an effective system of organizing students' independent learning activities in geography lessons. The students' independent work in the process of learning geography makes it possible to solve the following tasks:

1) to increase the awareness and strength of students' knowledge;

2) to develop skills and abilities required by the program for each course of geography; 
3) to teach students using the acquired knowledge, skills and abilities in life and social work;

4) to develop the students' observation, curiosity, logical thinking, creative activity, the need to acquire and apply knowledge;

5) to instill in them the culture of mental and physical labor; teach them to work independently, productively, with interest at creative tasks; to prepare students for effective self-education in the future.

The classification of students' independent work in geography lessons is given in Table 1 where the types of independent work are determined by the form and purpose of their use.

\section{Table 1. Classification of students' independent work}

\begin{tabular}{|c|c|}
\hline Type of work & \begin{tabular}{|l} 
Forms and purpose of independent work \\
\end{tabular} \\
\hline $\begin{array}{l}\text { For didactic } \\
\text { purposes }\end{array}$ & $\begin{array}{l}\text { 1. To update the basic knowledge and prepare for the perception of new } \\
\text { material. } \\
\text { 2. For studying new material. } \\
\text { 3. For systematizing knowledge. } \\
\text { 4. To consolidate knowledge and skills by performing training exercises. } \\
\text { 5. To consolidate knowledge by applying them in a new situation. } \\
\text { 6. Testing, control works. }\end{array}$ \\
\hline $\begin{array}{l}\text { By the nature of } \\
\text { cognitive activity }\end{array}$ & $\begin{array}{l}\text { 1. Copying, do according to the example. } \\
\text { 2. Partially exploratory. } \\
\text { 3. Exploratory }\end{array}$ \\
\hline $\begin{array}{l}\text { By forms of } \\
\text { organization } \\
\text { educational } \\
\text { activities of } \\
\text { students }\end{array}$ & $\begin{array}{l}\text { 1. Frontal. } \\
\text { 2. Group (with differentiated tasks). } \\
\text { 3. Pairs (according to options, differentiated). } \\
\text { 4. Individually differentiated. }\end{array}$ \\
\hline $\begin{array}{l}\text { According to } \\
\text { sources of } \\
\text { geographical } \\
\text { knowledge }\end{array}$ & $\begin{array}{l}\text { 1. With a book, reference book or other printed manuals, fiction. } \\
\text { 2. From drawing up a plan, lecture notes, based on what you have read or } \\
\text { listened to. } \\
\text { 3. From drawing up schemes after or during work with on-screen manuals. } \\
\text { 4. With handout cards. } \\
\text { 5. From the preparation of abstracts, reports, reports, projects. } \\
\text { 6. Compilation of tests, crossword puzzles, riddles, graphs, charts. } \\
\text { 7. Preparation for non-traditional forms of lessons. } \\
\text { 9. Writing a miniature work on these phrases. }\end{array}$ \\
\hline
\end{tabular}

In practice, a set of different types of students' independent work is reduced to independent activity. However, students' independent activity is not limited by doing tasks. It covers almost the entire educational process and is carried out at a different ratio of reproductive and exploratory activities of students [2].

It is necessary that the tasks offered to students for independent performance, were affordable for them and presented in a certain system. The basis of this system should be a gradual increase of children's cognitive independence carried out by complicating material and mental tasks, as well as by changing the role and level of teacher assistance. 
Independent work will be effective if it is carried out constantly based on a wellthought-out system of tasks. These can be tasks of half-independent, independent, mental operations (tasks for comparison, analysis, establishing causal relationships).

The system of tasks should be built, first of all, on the basis of the content of the geography course and sources of geographical knowledge. Depending on the specifics of the content of the geographical course and the age characteristics of students tasks can take the following forms: marking objects of geographical nomenclature on the contour maps; solving computational and analytical problems; determining the geographical coordinates of objects on the earth's surface etc.

Adaptive tasks have become widely used in school geography courses. These tasks require students to take personal responsibility and make their own decisions. These can be the following types of tasks: finding solutions to problematic questions and tasks, modeling the development of modern geographical processes and phenomena, formulation of conclusions and forecasting, performing group tasks.

With each subsequent course of school geography there is an improvement of tasks of independent work and conditions of their performance. It is desirable to diversify the types of independent work, both in form and content. They should force students to approach to the study of a particular issue from different angles. Another prerequisite for the systematic conduct of students' independent work is to increase the complexity of tasks and the conditions of work [5].

Easy tasks of independent work should include tasks that require answers to the questions: Where?, When?, How many?

For example: 8th grade. Section 4 «Population of Ukraine and the world». Task: Using a geography textbook and an atlas map, tell, what is the average population density of Ukraine? Where in Ukraine is the population density the highest, where the lowest?

In more complex tasks, it is proposed to explain the physical- or economicgeographical phenomena. In such tasks the questions are formulated: what for?, How?, Why?

For example: 8th grade. How does the ecological and financial-economic condition of the country affect the natural movement of the population? Why is there a decrease in natural population growth in the most developed countries?

The tasks of the theoretical direction, in which it is required to generalize facts and concepts are even more complex.

For example: Grade 9. What measures need to be taken to increase the competitiveness of light industry (production of fabrics, clothing, footwear) of the country? What are the main factors of placement of light industry enterprises?

The most difficult tasks of independent work are aimed at logical thinking of students. The following questions are asked: Explain why?, What is the reason?, Prove your opinion.

Grade 10. Solve the problem: Is there a direct dependence between the available natural resources and the development level of individual European countries? Justify your answer, give examples. 
The most difficult are creative research tasks, which are aimed at developing creative and critical thinking of students. Examples of such tasks are the preparation of projects, essays, presentations, reports, compiling crosswords, riddles, diagrams.

Grade 10. Prepare a project «Subregions of Europe», which aims to acquaint high school students with the peculiarities of development, different subregions of Europe, finding their common and distinctive features, the pros and cons of economic and geographical location.

Teachers' experience and research show that students' independent work in geography lessons contributes to strong knowledge, the formation of the ability to learn without anyone's help.

Let's move on to assess the effectiveness of various forms and types of independent work of students in practice (Fig. 1).

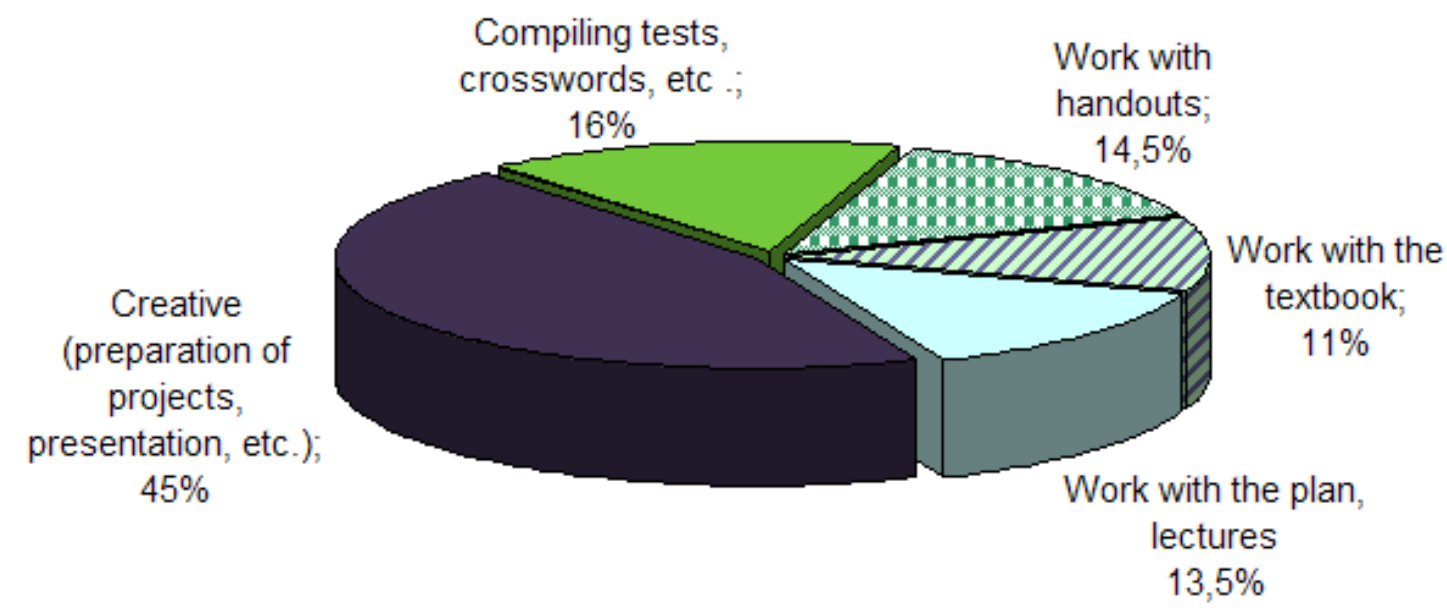

\section{Figure 1. The effectiveness of types of independent work by sources of knowledge}

This diagram shows that creative types of students' independent work (preparation of projects, abstracts, messages, presentations, reports, etc.) were the most effective in practice. These methods are effective both in the lesson when learning new material and when students do homework.

It is due to the fact that these types of independent work involve high activity of students. Children independently, but under the guidance of the teacher prepare projects, essays, crosswords, make comparative tables, which contribute to the strong assimilation of the material. These types of independent work contribute not only to the acquisition of geographical knowledge, but also to the development of a creative personality.

Such types of students' independent work, as «working with a map» proved to be ineffective, because many students have poor skills in working with atlas maps, comparing them, obtaining information from them. The same tendency is observed at working with the textbook, because the majority are badly able to allocate the main thing, generalize the facts, concepts. Only a few students are good at working with information. 
If we evaluate the classification of students' independent work by the nature of cognitive activity (Fig. 2), the most effective were exploratory tasks, because they involve a creative approach to perform tasks and design research results.

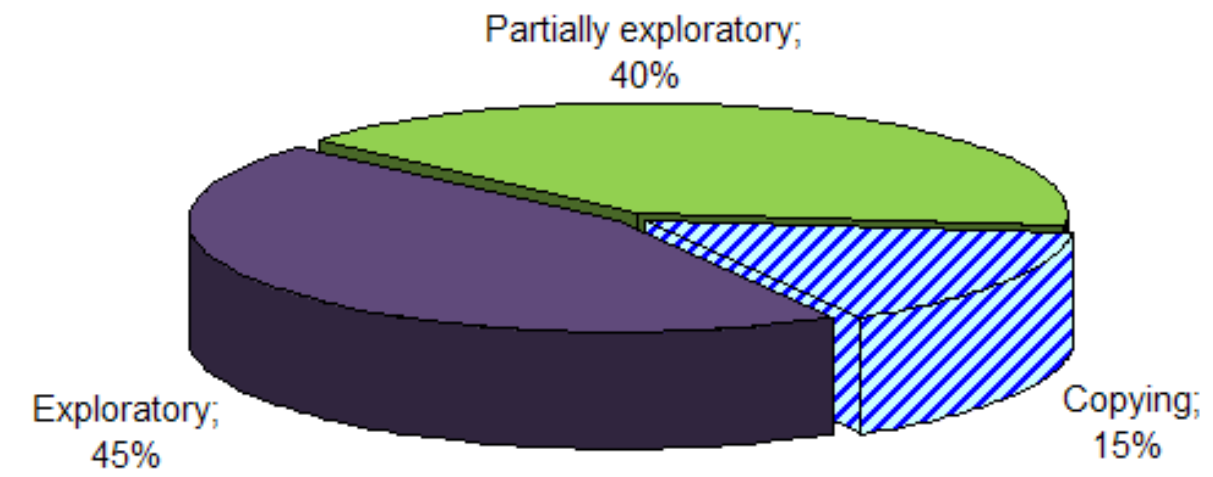

\section{Figure 2. The effectiveness of types of independent work by the nature of cognitive activity}

Partially exploratory tasks, which are based on students' logical thinking, the ability to argue their point, to think critically, proved to be quite effective. It can also be a task of theoretical direction, in which it is required to generalize facts, concepts, etc.

The least effective were copying tasks, which are performed according to a sample and do not involve elements of creativity, because they are passive.

Thus, the effectiveness of students' independent learning activities increases if at different stages of the lesson a system of learning tasks built on the principle of increasing the level of cognitive activity is used. As students move from class to class, their level of knowledge and cognitive abilities increase. As a result, the types of independent work are gradually becoming more complicated.

Discussion. In today's dynamic world, the requirements for education are also changing. The main task of modern teachers is to prepare students for independent living, teach them to acquire knowledge independently, make decisions, learn throughout life, constantly improve themself, to educate them to be critical thinking people, creative, able to defend their views, argue their opinions, have productive discussions, etc. One of the main methods of educating such person is the students' independent work.

Successful development of human thinking can be carried out only under the condition of independent search, independent activity. Students acquire knowledge only in the process of independent educational activity, which covers almost the entire educational process and is carried out at a different ratio of reproductive and exploratory activities of students.

The effectiveness of the method is explained by the fact that children independently choose the type of their cognitive creative activity and perform tasks in the sequence that satisfies them, forming and developing the ability to work with different sources of geographical information. Most types of independent work involve students' high activity and are aimed at the development of creative and 
critical thinking, contribute not only to the acquisition of geographycal knowledge, but also to the development of creative personality.

The structure and content of school geography course promotes independent creative activity of students in class and after school. However, this activity involves the teacher's guidance of the educational process. The teacher explains the motive, the goals of the students' work, makes a plan, develops the structure of the study, formulates leading questions, corrects, clarifies, conducts instruction before the start of independent work in oral, written and visual form. In doing so students perform the teachers' tasks without his help.

The general methodical recommendations on the organization and carrying out of independent work in the basic school geography courses include the following:

1) in the process of planning any type of independent work, a geography teacher must: clearly define its purpose, main tasks, means of implementation, regulations, final result, verification form and evaluation criteria;

2) before performing independent work, it is obligatory to conduct appropriate instruction regarding the performance of work, sources that can be used, method of presenting results, evaluation system, etc.;

3 ) it is desirable to remember that for a particular type of independent work you need to plan the optimal time for its implementation, consider students' age characteristics;

4) during independent performance of the tasks by pupils it is necessary to observe attentively their educational activity, to hold current control, if necessary to carry out consultations;

5) to conduct independent work in the classroom, it is desirable to use more often a group form of organizing students' educational activities, which has many advantages and gives the teacher an opportunity to immediately check its results;

6) at the end of independent work the result is checked [1, p. 115].

Although the independent work of students is reduced to independent activity, the teacher's control over the implementation of tasks is mandatory. Much depends on the pedagogical skills of teachers, the ability to organize independent work of students, to manage it.

Results. Teachers' experience and research show that students' independent work in geography lessons contributes to strong knowledge, the formation of the ability to learn without anyone's help.

Independent work in geography lessons has great educational and upbringing value. It can give the desired results only if the teacher uses it in a certain system and sequence; manages it correctly.

The students' independent work is classified according to its didactic purpose, the nature of cognitive activity, forms of organization of students' educational activities, sources of geographical knowledge.

As students move from class to class, the level of their knowledge and cognitive abilities increase, so the types of independent work must be gradually complicated. 
For the systematic conduct of students' independent work in geography lessons it is necessary to increase the complexity of tasks and the conditions of their implementation.

The most effective types of students' independent work are creative and exploratory tasks (preparation of projects, messages, presentations, reports, etc.). Such tasks involve students' creative approach to their implementation and design of research results, give students the opportunity to be creative, develop critical thinking, the ability to work with information, process it, make independent conclusions, solve problems.

The least effective were the tasks of a copying nature, which are performed according to a sample and do not involve elements of creativity.

\section{References:}

1. Kobernyk, S.G. (2012), Naukovo-metodychni zasady geografichnoi osvity [Scientific and methodological principles of geographical education in primary school], K.: NPU im. M.P. Drahomanova, 345 p. [in Ukraine].

2. Kobernyk, S.G. (2005), Metodyka navchannia geografii v zagalnoosvitnih navchalnyh zakladah [Methods of teaching geography in secondary schools]: posibnyk, Kyiv : Navchalna knyga, $319 \mathrm{p}$. [in Ukraine].

3. Koncepcia geografichnoi osvity $v$ osnovniy shkoli. [Electronic resource] / URL: http://undip.org.ua/info/1023/ [in Ukranian].

4. Krit, N.V. (2016), Netradyciynyi pidhid do vykorystania pidruchnyka z geografii u formuvanni vmin samostiynoi roboty uchniv 6-8 klasiv [Unconventional approach to the use of a textbook on geography in the formation of skills of independent work of students in grades 6-8 / Krit N.V. // Collection of scientific works «Pedagogical Sciences» of Kherson State University], Kherson: Ed. House «Helvetica», 145-151. [in Ukraine].

5. Medvedev, M. (2010), Samostiyna robota I samostiyna dialnist ychniv pid chas vuvchennya geografii Ukrainy [Independent work and independent activity of students during the study of geography of Ukraine // Geography and basics of economics at school], 2010. №1. pp. 18-20. [in Ukraine].

6. Sergeev, I.S., Blinov, V.I. (2007), Kak realizovat kompetentnostnui podhod na uroke vo vneurochnoi deitelnosti [How to implement a competency-based approach in class and in extracurricular activities: Practice. Allowance], - M.: 132 p. [in Russian].

7. Zhuravlyova, L.S. (2018), The problem of organizing independent activities of students in primary school: socio-pedagogical aspect. International scientific conference, Kaunas, Lithuania, pp. 23-26. 